\title{
Utado?! Bad Manners, Incivility, Impunity and the Legacy of Autocracy in Kenya ${ }^{i}$
}

\author{
Dickson Ombaka
}

Department of Sociology, Kenyatta University, Nairobi, Kenya

Copyright $\mathrm{C} 2018$ by authors, all rights reserved. Authors agree that this article remains permanently open access under the terms of the Creative Commons Attribution License 4.0 International License

\begin{abstract}
All over the world today many people are complaining of increasing displays of bad manners and incivility in society. It seems that good manners and civility are fast disappearing from social interaction not just in interpersonal relationships but in public affairs as well. Whether it is in the United States, the Philippines, or in Kenya, political leaders today are more likely to feature in the news not for the positive life-changing things they intend to do for their people but more likely for their invective against perceived foes. This paper argues that the bad manners and incivility that are being witnessed from Kenya's leadership today are a necessary precondition for the acts of impunity that are occurring with greater frequency. These acts of bad manners, incivility and impunity are best expressed in the Sheng word: utado?! This word not only describes an attitude but also defines a whole culture in the conduct of public affairs in Kenya. These sundry acts of bad manners and incivility far from being accidental are deliberate and are a precursor for the increasing acts of impunity. These acts of impunity demonstrate the dearth of civility whose ultimate outcome may be to turn away from a new-found democracy to authoritarian governance of the past.
\end{abstract}

Keywords Utado?!, Incivility, Bad Manners, Impunity, Autocracy, Authoritarian Rule

\section{Introduction: Utado?! As an Expression of Bad Manners, Incivility and Impunity}

Utado?! is a word of the patois, Sheng. Sheng is mainly a mixture of Kiswahili and English ( $\boldsymbol{S}$ wahili $+\boldsymbol{E n g l i s h}$ ) as well as smatterings of other Kenyan languages that evolved in Nairobi's inner city from the 1950s [1]. A literal translation of the word may be rendered as "what will you (uta) do (about xyz)"? or "what are you going to (uta) do (about xyz)"? This literal translation conveys a sense of solicitous concern that one may express toward another person in trouble or in a difficulty enquiring about what their next course of action will be. However, the literal translation is far from the actual, nuanced meaning in which the word is often used today. If it is uttered in just the right tone, it is at once a contemptuous dare, a challenge, a taunt more in the sense of, "so, what the ${ }^{* * * *}$ are you going to do about it"?! It is the universal language of the schoolyard bully, the village lout and the amoral gangster. It is an expression of unequal power relations. It is a word that someone in a position of power (real or imagined) uses towards another person who s/he perceives as being relatively powerless. It is therefore a particularly open expression of bad manners, incivility and impunity. It basically says that "I do not much care whether what I am doing is immoral or illegal because there is nothing you can do about it". Although its origins are in the inner city and the power elite may not deign to utter it in public, its meaning and intent is often reflected in their attitude and their behaviour. What I want to do in this brief paper is to look at how the attitude of bad manners, incivility and impunity expressed in the word utado?! has increasingly defined Kenya's public spaces in the recent past to an extent that it describes a culture. Indeed, how the ruling elite have so thoroughly immersed themselves in this culture to the extent that through their daily actions and utterances they now seem to ask Kenyans "mtado"?! (the plural form of utado?!).

Although the word itself may only be a few decades old, the attitude and indeed the culture that it expresses has a long history. It is an attitude that marks the unequal power relations not just in interpersonal relationships but between Kenyans and those who rule over them. It is therefore an attitude that has permeated the Kenyan social fabric to a greater or lesser extent. It is an attitude that has been nurtured by the ruling elite right from the colonial period to the present [2]. In the public sphere it is therefore an attitude that is born of an intention to disregard the rights of citizens and a desire to impose the will of elite on the rest of society. It is an attitude that has been an underlying theme running right through Kenya's political history [3]. Further, 
it is an attitude that has been fuelled along by corruption on the one hand and tribalism on the other hand. The corrupt invoke utado?! to underwrite their impunity. Whenever there appears any possibility of their corrupt ways being punished, their corrupt actions cease being of an individual or group of individuals and is somehow transformed into their whole tribe that is being targeted. The tribe, thus implicated, then invariably raises its voice to defend one of its "own" against such unwarranted persecution! The utado?! of the ruling group is therefore socially created. It is a culture that is perpetrated and perpetuated by the various publics that are enticed through corruption and tribalism to fight, often unconsciously, in favour of bad manners, incivility and impunity in the false belief that it is only for the collective good of their tribe and for "peace" in the country [4]. And it all begins from a basic lack of good manners.

\section{From Good Manners to Civility}

Quite often in common usage good manners and civility are used as synonyms. This is understandable because there is a connection between the two. However, for this discussion I prefer to make a small but important distinction by proposing that although good manners and civility are on one positive continuum of behaviour there is a difference in terms of precedence. Good manners are prescriptions for behaviour that will vary from one culture to another. As a cultural attribute the acquisition of good manners is the result of a successful socialization process that begins at childhood and continues throughout life. As Friedman [5] notes, the main purpose of acquiring good manners is to enable us to live much of our lives in unthinking patterns. Good manners allow us to devote our time and thoughts to more pressing matters than how to greet someone or to wait for our turn to serve food. Through socialization good manners become second nature. They establish a framework for social rituals that enable us to live peacefully with each other. Indeed, even when disagreements erupt, as they occasionally will in any society, it is good manners that provide the framework in which reconciliation is made possible. It is good manners that enable us to feel a sense of shame. Thus, a shameless person is most likely to be also bad mannered and in all likelihood uncivil.

Civility as a concept appears in the fourth century BC in ancient Greece with Artistotle's use of the expression "koinonia politike" to refer to the type of human connection that happens in the polis (city) and the agora (gathering place). It is different from the type of relationship that we find in the private sphere such as the family. In the polis, strangers gather as equals and how one treats strangers is therefore the measure of one's moral excellence [6]. According to Norbert Elias [7] governance or more commonly, administration, is enacted through rules of civility, or manners of behavior in the public sphere. In this public sphere, however, there is a distinctive difference. Democratic civility, unlike good manners that become second nature, is not a natural state but a practice that demands work and is therefore one of the accomplishments of civilization across cultures. Indeed it is this civility that makes democracy possible and the two concepts are therefore inextricably linked.

As such it may be said that many of the rules of civility are already practiced by people with good manners because good manners are the antecedent of civility. Good manners, therefore, are the result of successful socialization from childhood that in later life may serve to make one civil [8]. While good manners are taught and learned from childhood and throughout one's life, for this discussion civility is seen as a later development that is also built concurrently and overlaps with good manners. Although both good manners and civility are outward directed in that they define one's relationship with "others", in the final analysis civility is more applicable to the public realm than the interpersonal, private spheres where good manners tend to take precedence. As such civility is specifically relevant in relationships with those we do not know and yet our ability to be civil depends in no small measure on whether we have good manners to begin with. This relationship between good manners and civility is illustrated in Figure 1 below. Thus, in the public space if we see bad manners we are seeing the symptoms of incivility. If we see incivility we are seeing the symptoms of impunity. And if we see impunity we see a tendency towards autocracy rather than democracy for civility is the very foundation of democracy.

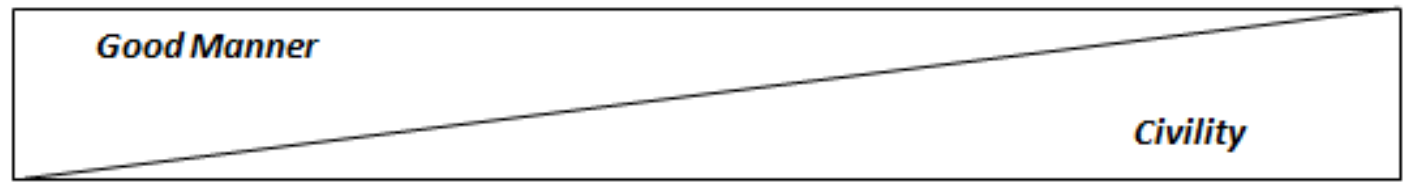

Figure 1. The relationship between good manners and civility 


\section{Civility and Democracy}

Among the many virtues that are vital for the "common good" in a democracy, civility occupies a prominent position. Although many people are predisposed to dismiss it as a thin or procedural virtue, civility is in fact vital for a democracy. In reality the hallmarks of democracy such as freedom of thought, religious freedom, press freedom and the right of association are nothing less than institutions reflecting a presumed civility [9]. Those who argue against civility such as Herbert Marcuse [10] decry its conservative bias. Marcusse [11] argues that practicing civility only hobbles the dialectical confrontation that is needed for systemic reforms or revolution. This is a valid point. Faced with cataclysmic evil, civil discourse would be morally reprehensible; only righteous indignation and rage would be appropriate. So is it possible for this very same virtue of civility that is so vital for democracy to turn into vice? When, then, does civility stop being a virtue and become vice [12]? When democracy itself is abandoned, because without civility there can be no democracy.

Civility is therefore more than just polite courtesies. As Hacala [13] explains, civility is derived from the Old French and Latin terms for "good citizen", and it is what enables us to live respectfully in communities; it is the glue that binds society. Conversely people cannot be civil if they are not schooled in good manners because it is good manners that lay the foundation for the rules of civility in any culture [14].

Democracy works only if people have cultivated the specific virtues that can enable them to work for the common good and civility is near the heart of these virtues. In a democracy, people must be able to deliberate and reflect on issues that affect them and such deliberations are premised on citizens' ability to speak and listen to one another with openness and respect, i.e. with civility.

According to Richard Boyd [15], civility is a restraint on political discourse and this restraint is also a form of democratic care and solicitude. With both restraint and solicitude, civility makes it possible to hope not only for the existence of a democratic space but social solidarity as well [16]. Ethnographic studies [17] demonstrate that civility is an activity through which we try to make comprehensible two dimensions of the public: how we expect to be judged by others and an affirmation of how much we value this judgment. It is therefore an activity of defining how to behave properly and fairly with and among others [18]. Therefore, civility is ambivalent in nature in that it acts both as a constraint and a threat on the one hand and as a requirement to honour and therefore a means of democratic socialization on the other. It has to do with meddling, intervening, talking, showing care and solicitude, sometimes fighting and trying to teach things to others. As Gayet-Viaud [19] notes, being strangers to one another is not an obstacle but the very condition of civility. That is to say that it is as strangers that we need to grant each other respect and trust.

Civil interactions are those encounters in public where individuals experience others as strangers [20]. In such encounters people are exposed to the gaze of others upon them and the judgments that are made from these experiences. When studied as an activity, therefore, civility is one of the ways in which citizenship is experienced. As Gayet-Viaud [21] explains, civility means a way of trying to define not only what should be done but what can actually be done even at the very moment of doing it; it is the major indicator of the state of the political and moral culture of a democracy. Therefore, where civility is lacking, the political and moral culture of a democracy are at imminent risk and autocracy becomes an increasingly attractive possibility for those in power.

This is why it is disturbing that unlike in times past it seems that the obligation that we should appear to respect persons with whom we disagree has been totally lost. And yet, good manners, as Friedman [22] observes do not ask you to lie to yourself, but merely to the rest of the world. We seem to have largely lost this capacity or desire to lie to the world and in doing so we have succeeded in making our public spaces most uncivil.

\section{How the Road to Autocracy is Paved with Bad Manners, Incivility and Impunity}

All around the world today many people are complaining of an increase in bad manners and incivility. Such acts characterize not just interpersonal relationships but the conduct of public affairs as well. It seems that in today's world, it is no longer deemed necessary to feel shame, hide or disguise our malice. Good manners and civility have been thrown out the window. As Barack Obama [23] observes:

We see the utter loss of shame among political leaders, where they're caught in a lie and they just double down and lie some more. Look, let me say: politicians have always lied, but it used to be that if you were caught lying, they'd be like, "Ah, man".

All over the world it seems that politicians have decided that honesty means expressing their utter contempt for those with whom they disagree [24]. In this way adversaries become enemies before they are transformed into monsters. Whether it is President Donald Trump of the United States, President Rodrigo Duterte of the Phillipines or President Uhuru Kenyatta of Kenya, bad manners and incivility appear to be in ascendancy [25-27]. Although bad manners and incivility are a perennial problem that each preceding generation seems to find in succeeding generations, there is an important difference in contemporary times. The Internet, has greatly contributed to the blurring of boundaries between what was formerly 
described as the private and public spheres respectively [28]. This easing of communication has certainly contributed to the feeling (rightly or wrongly), that bad manners and incivility are in ascendancy today, more than ever before. Whether such bad manners and incivility are in the "private sphere", social media has significantly shifted the boundaries of that private space and made it public, while ensuring that the "public sphere" in its turn has never been more public than it is today. So, perhaps even bad manners and incivility that would not have come to our attention previously because they were private now join in with what happens in the public spaces to add to our sense of being overwhelmed by bad manners and incivility.

It is something of a truism that traditional customs in Africa greatly value civility and decorum. This is readily apparent not only in the anthropological studies of customs and traditions but in traditional folk tales as well. Many of these tales are replete with animal characters that represent human characteristics and behaviour [29]. The motif of virtually all these stories is the triumph of decorum and civility over bad manners and incivility. This is not to suggest that incivility and bad manners did not exist in these societies; that was the reason for these stories in the first place. However, there existed very effective methods of both formal and informal sanctions that kept people in line; no one got away with bad manners and incivility and these stories in themselves were a civil way of criticism and sanctioning such behaviour [30]. Sanctions existed to ensure that the uncivil were punished in various ways and in the extreme, even exiled from society.

This is something that is true not only of African traditional societies but of many other traditional societies that have existed around the globe. Bad manners can never describe the character of a whole community or society because it is not characteristic for societies to let the uncivil get away with incivility. Considering the nature of human societies and the way they are structured, there can be no doubt that civility rather than incivility is the true basis of any society. This is because society is to a large extent based on cooperation. A society's culture in turn regulates the forms and substance of such cooperation. Thus, while the term "civility" itself may be defined in many different and even contradictory ways across different cultures there is no doubt that in the context of any one culture, behaviour that is civil will tend to be the rule rather than the exception. Without civility there would be no social order, no decorum, and no respect. This is why Evans-Pritchard [31], for example, in spite of describing the Nuer of Sudan as people who are easily aroused to violence nonetheless display much decorum and civility in their interpersonal relationships.

If social order rests on cooperation, then civility is the basis of that cooperation. In this sense an uncivil society would be a contradiction in terms. However, cooperation is not the only feature of society. Because of human nature and the nature of societies, conflict is also an undeniable feature of societies. Thus, cooperation and conflict must be viewed as opposite sides of the same coin. Because of this fact society, if it is to remain stable, has to strike a balance and ensure that conflict never overwhelms social order. It is civility that enables society to strike this balance. This is to say that in the numerous "tosses" of the coin called social intercourse there must be more "cooperation" than "conflicts" coming tops.

Bad manners, incivility and impunity are therefore social features that undermine cooperation and can therefore disrupt social order. To that extent we may associate them with conflict because they are frequent accompaniments of conflict. Conflicts are not necessarily bad and their management and resolution are often a necessary part of the process that leads to social change and development. However, if society is to maintain cooperation for any length of time, bad manners, incivility and impunity must never be allowed to overwhelm good manners, civility and the rule of law. For cooperation, it is the latter that must characterize social intercourse. A society that allows the balance to tip in favour of bad manners, incivility and impunity is on the road to disorder to which autocracy often presents itself as the only remedy.

This means that in any society the mere presence of bad manners and incivility will generally not detract from the basic fact that good manners and civility provide the basis for the social interaction of the majority of its members. What may distinguish one society from another is the degree to which such bad manners and incivility are tolerated or condemned and sanctioned. It is important to note that bad manners and incivility are not necessarily punishable by law; behaving badly or in uncivil ways may not actually break any law. However, by definition they reflect a range of behaviours that if not actually punishable, are devalued by the rest of society. And they are devalued because their ultimate effect is to undermine social harmony. Therefore, when there is frequent failure to sanction bad manners and incivility, then impunity is born. This is because what ought to be punished goes unpunished and with time is seen as a mere nuisance before it is finally tolerated. What is not acceptable becomes tolerated by default and those who behave in this way can now act with impunity. Thus in the public sphere, what should be forbidden is first thought of as a "mere" nuisance and then becomes tolerated. With time, democracy that requires civility and good manners gives way to autocracy or dictatorship that tends to thrive on bad manners, incivility and impunity.

According to Adamson [32], the state always has a tendency to favour authority. The authoritarian approach tends to be attractive because it does not require too much thinking. Leaders are therefore often attracted to it hence Lord Acton's [33] dictum: "power tends to corrupt, and absolute power corrupts absolutely". In politics where interests tend to reign supreme, authoritarianism is therefore a tempting prospect for those in positions of 
leadership. Democracy is relatively more difficult because it demands consultations and negotiations with numerous others who may have a stake in a decision [34]. It is for this reason that democracy's best defense lies in the creation and maintenance of strong institutions to check against this tendency among leaders. In countries that have failed to establish strong institutions to counter this "natural" desire of rulers to have their way, democracy may not survive and such countries could more easily revert to autocracies. This is the distinction between the "mature" democracies such as the United States and "struggling" democracies such as Kenya's. That as much as President Donald Trump of the United States may display bad manners and incivility his ability to follow them up with impunity is severely limited. This is because American society has established robust institutions to frustrate precisely this kind of tendency towards authoritarianism no matter how strong it may be. These institutions do not make America immune to dictatorship; they just make it more difficult to impose. This is in marked contrast to a country such as Kenya where the bad manners and incivility of state actors are more often than not directed towards those very institutions that would act as a bulwark against impunity. The capture of these institutions is the aim of the bad manners, incivility and impunity of the ruling elite in Kenya today. When the bad manners and incivility have done their part, impunity follows and autocracy becomes a most likely destination.

\section{How Incivility has Bred Impunity in Kenya}

According to Spath and Dahnke [35], "civility is claiming and caring for one's identity, needs and beliefs without degrading someone else's in the process". Although politeness is a necessary first step, civility is more than just politeness. Indeed Gunderson and Lea [36] have developed a civility model that stresses the idea that civility is a sequence rather than a single thing or set of things. Arnett and Arneson [37] define civility as "a metaphor that points to the importance of public respect in interpersonal interactions". It is a personal attribute that acknowledges other humans' right to live and coexist together in a manner that does not harm others.

Incivility, on the other hand, is the direct opposite of civility, or in other words a lack of civility. Whether it consists in verbal or physical attack on other people, cyber bullying, rudeness, religious intolerance, lack of respect, urinating in public, discrimination, or vandalism, all these describe a range of uncivil behavior [38]. Incivility is a part of society that impacts negatively on those on whom it is practiced [39]. In Kenya today many drivers, especially of public service vehicles, known as matatus (minibuses and vans) see nothing wrong with behaving doltishly towards other road users by obstructing and doing all kinds of illegal things that they were definitely not taught in driving school. In the education system, cheating in national examinations has thrived for a long time. It begins early in primary school so that by the time such dishonest students get to university, cheating has become an accepted way to get ahead of others. When they get caught apart from the expected denial a common enough reaction is not one of shame or contrition but rather of regret that they were caught! And the list goes on and on and on.

In the public sphere, Kenya's socio-political history is to a large extent described by the culture of utado?! As already noted, the logical end to bad manners and incivility in the public arena is impunity and those who can get away with acts of impunity are those in power who have captured and control the instruments of punishment. The behaviour of state actors in Kenya over the last few years can be described by the word utado?! Unfortunately, it is not only state actors that are implicated but their political competitors in the opposition as well. Despite the fact that it is those who are in charge of the state that are encouraging impunity, the political opposition is no less complicit. This is what makes it an epidemic of bad manners, incivility and impunity and leads to the legitimate question of whether an alternative leadership would be any less predisposed to acts of impunity. Because the answer to this question is moot, in this paper I focus on the state actors by virtue of the fact that they not only swore to defend the Constitution but are by that token obliged to set the standards. On any single day in the last few years, one need only look at a newspaper to find this totally flagrant demonstration of utado? by those in power and their overzealous agents [40-42]

As noted above, in the normal order of things, bad manners and incivility are sanctioned in various ways by society. The fact that many instances of bad manners and incivility are now tolerated and are in most cases even encouraged by those who should sanction it is what distinguishes the Kenya of today from traditional society of yore. Such encouragement is deliberate rather than random and accidental and can only mean that those in power are trying in effect to replace the democracy that is guaranteed by the Constitution with a more authoritarian brand of leadership. It is these seemingly random acts of omission and commission that eventually lead to impunity, to tolerance of that impunity with time and eventually to the possibility of establishment of authoritarian rule. It is what Obama [43] has so aptly described as the emergence of "strongman politics" that have made these times so "strange and uncertain" not just in the United States but around the world as well.

Impunity may simply be defined as exemption or immunity from punishment. As Makabenta [44] notes, it is this exemption that is sometimes more outrageous than the crime itself. Behaviour that deserves punishment should be punished. That must be the basis of any society that is ruled by law. The United Nations Commission on Human Rights [45] in its Principles for the Protection and Promotion of 
Human Rights through Action to Combat Impunity says the following:

Impunity arises from a failure by states to meet their obligations to investigate violations; to take appropriate measures in respect of the perpetrators, particularly in the area of justice, by ensuring that those suspected of criminal responsibility are prosecuted, tried and duly punished; to provide victims with effective remedies and to ensure that they receive reparation for the injuries suffered; to ensure the inalienable right to truth about violations; and to take other necessary steps to prevent a recurrence of violations.

In Kenya, impunity in the public sphere is not a new phenomenon and can be traced back to its colonial history spanning a period of some 60 years. In fact the whole colonial enterprise in Kenya (and elsewhere for that matter) may be regarded as nothing more than a demonstration of impunity [46]. History has demonstrated time and again, that the oppressed often learn from their oppressor. In this light the fact that impunity has been such a ubiquitous feature of public life in independent Kenya may not be so difficult to explain. To the extent that impunity is characteristic of societies that suffer from corruption, or that have entrenched systems of patronage, or where the judiciary is weak, or where members of the security forces are protected by special jurisdiction or immunities, Kenya is or has been a good candidate on many or on all of these accounts. This was especially true for the period between 1969 and 1991 when Kenya was first a de facto and then a de jure one-party state. So far, this period of Kenya's political history marks the height of bad manners, incivility and impunity by the state [47], but only so far. This is because in the very recent past there have been serious indications that show a possible return to those days.

\section{The Impunity Template: What is Good for the Goose is not Always Good for the Gander}

Although the roots of utado?! run deep, the present trend of bad manners, incivility and impunity by the state and its agents can be traced back to the recent life histories of President Uhuru Kenyatta and his deputy, William Ruto, the duo commonly going under the label UhuRuto. UhuRuto were indicted at the International Criminal Court (ICC) at The Hague for crimes against humanity arising from the post-election violence (PEV) of 2007/2008. However, on 5 December 2014, the ICC was forced to drop charges against President Uhuru Kenyatta, just as they later had to drop the charges against his deputy, for "lack of evidence". This evidence was interfered with, corrupted or literally gotten rid of through acts of bad manners, incivility and downright impunity [48]. This result was achieved through several actions by the Kenyan government to undermine efforts, including those by the ICC, to ensure accountability for victims of murders, rape, displacement and police brutality committed during the post-election violence of 2007. UhuRuto used seven main tactics to kill the cases against them at The Hague [49] and it is these tactics that have subsequently served as the template for the state's path to impunity since 2014 .

They are tactics that are aimed at achieving the ultimate goal of taking Kenya back to the days of the pre-2010 Constitution when an imperial presidency reigned supreme and dissent was punishable, sometimes by death. The architects of this post-colonial authoritarian era were the first president and Uhuru's father President Jomo Kenyatta (1963-1978), and his successor President Daniel Arap Moi (1978-2002), the latter who ruled virtually unchallenged for 24 years and became Uhuru's mentor. These are the role models of UhuRuto and one sometimes senses in President Uhuru's behaviour a certain frustration with the present constitutional arrangements and a nostalgic desire to rule "like Daddy". These tactics are therefore not new and are usually applied just as, or even more crudely than when they were first used some decades ago. These acts more often than not echo Karl Marx's [50] observation about what happens when history repeats itself: "the first as tragedy, then farce". At any rate UhuRuto have come to depend greatly on tactics that they believe worked well for their role models in the past. In this way bad manners have given way to incivility and incivility in turn has led to impunity. It is the argument in this paper that this impunity is not only a threat to the rule of law but to democracy and may easily lead to a return to the authoritarian past from which it took Kenyans so long a struggle to break away from.

A sampling of these seven tactics will suffice for illustration in this brief discussion. One of the hallmarks of the practice of state impunity by UhuRuto has been the selective application of the law in favour of their political allies and the highly discriminate use of state power and force against their political opponents. It is such calculated and cynical practice of impunity that has led some supporters of UhuRuto to praise and justify highly autocratic and immoral use of state power to suppress the rights guaranteed by the Bill of Rights in Kenya's Constitution. It is such application that fools some publics into thinking that it is alright to break the law in order to ensure "peace" and short term ethnic and political interests of elite, elite that in the final analysis has nothing but contempt for an often gullible public.

Tactic \# 1: The first tactic is to rob some key institutions of their substance while keeping up appearances about their role. An example of this was when the Kenya government quietly denied adequate funding for the witness protection agency that was supposed to protect the post-election violence witnesses. Instead of funding it fully the government gave it only 15 per cent of its budget 
requirements thereby ensuring that it was moribund and hardly capable of even protecting itself, let alone witnesses [51]. This effectively left the witnesses exposed to all kinds of mischief and starved the ICC cases of crucial evidence. Obviously, the witnesses for the defense were not affected by this selective treatment. In the post-ICC era this tactic has continued to be useful. Many constitutionally established institutions whose mandate is to check excesses of government are routinely starved of funds or/and are under constant threats of dissolution. This tactic is meant to ensure that they cannot aggressively pursue their legal and constitutional mandate to keep the executive in check. Such is the case with the Office of the Auditor General that has experienced concentrated and focused efforts to emasculate it [52]. Early in 2018 despite the fact that all members of parliament are entitled to bodyguards paid for by the state, the bodyguards for some opposition members of parliament were unilaterally withdrawn [53]. Needless to say, those members of parliament belonging to the UhuRuto side in the Jubilee Party were not affected by this unilateralism.

Tactic \# 2: The second tactic is to block investigations and prosecutions that could cast the government in a bad light. UhuRuto were sent to The Hague as people who bore the greatest responsibility for planning the post-election violence [54]. However, those who actually carried out the killing and raping were supposed to be prosecuted locally. In the event not even a single case of sexual violence or murder committed in the post-election violence has been successfully prosecuted [55]. This was also accompanied by the failure to prosecute even a single mid- or senior-level perpetrator associated with the PEV. At the same time there were clear cases of bribery, intimidation and killing of ICC witnesses or people thought to be witnesses as a way of frustrating successful prosecution [56]. In the post-ICC trial era this strategy has also been well utilized. Many cases of wrongdoing on part of state agents have been casually ignored. Of the more than 300 killings done in the opposition zones by the police and other state agents in the elections of 2017, none has been prosecuted, and not a single senior officer has been made to take responsibility [57]. If anything, the president came out and praised the police for the "good work" they had done [58]. While opposition supporters were whipped, shot at and killed for protesting the outcome of the August 2018 presidential elections, supporters of UhuRuto who came out to celebrate the "victory" were not subjected to the same brutality although they also did it on the streets and other public places. This is how impunity creates two classes of citizens; those to be brutalized and those to be protected.

Tactic \# 3: The third tactic is to ignore the victims of state violence who belong to the political opposition. After the PEV, victims identified as belonging to the opposition were not provided with any security, emergency or ongoing medical assistance. When the Kenya Truth,
Justice and Reconciliation Commission recommended the establishment of a reparations mechanism to benefit victims, this recommendation was selectively applied only to benefit those who were perceived as government supporters. Ten years later and counting, victims from the opposition continue to languish. In the post-ICC trial era the victims of state perpetrated violence and impunity are still ignored [59]. Once again impunity creates two classes of citizens: those who are to be recognized and those who are to be ignored.

Tactic \# 4: The fourth tactic is to disregard the courts and established procedures. Following the post-election violence, cases where police shot and killed civilians were not pursued with any seriousness and those police officers whose cases actually came to trial were acquitted on quite dubious grounds [60]. In the post-ICC era, this callous disregard of the courts of law is self-evident. Whether it is in the president referring to the Supreme Court Justices as "crooks" and threatening to cut them down to size for ruling his August 2017 election null and void [61], or in the Minister for Interior describing the judiciary as "evil" and stubbornly refusing to obey ten court orders, the courts (and by extension the rule of law) are regarded as nothing more than a nuisance to the will of UhuRuto [62]. Once the authority of the courts has been undermined by the state the citizen has no protection against impunity and autocracy.

Tactic \# 5: The fifth tactic is to attempt to rig the system whenever the system is not in their favour. In the trials at The Hague UhuRuto used this tactic in an attempt to get around the ICC when it appeared to them that the system was not going to work for them. They therefore attempted to amend Article 27 of the Rome Statute and establish immunity for heads of state through the United Nations [63]. When that approach appeared unpromising they sought to expand the jurisdiction of the African Court of Human Rights to cover the Rome Statutes crimes. In the post-ICC trials era, such attempts to rig the system whenever they have deemed it unfavourable have continued. Indeed, the perceptions of the opposition that the electoral body was itself rigged to deliver a favourable result for UhuRuto's Jubilee Party was the cause of the tensions before and after the 2017 general elections. After the nullification of the August 2017 presidential poll there was a frantic effort by the Jubilee Party to amend the electoral laws before the repeat polls to ensure that Jubilee would have a law more favourable to its interests than to the opposition [64].

Tactic \# 6: The sixth tactic is to manipulate the state apparatus, at whatever cost, to achieve the narrow short-term outcomes that they want. After their indictment at the ICC, UhuRuto applied this tactic to the cause of getting an acquittal at The Hague. UhuRuto, against much opposition to their candidature in light of the serious charges facing them at The Hague, made a deal to be on the same ticket and they actually ran their 2013 campaign on an anti-ICC platform. Diplomats were sent left and right to 
press for the deferral of the ICC cases. In the post-ICC era, and more particularly since 2017, there have been unrelenting efforts to harness the state apparatus to work for the interests of UhuRuto against the opposition [65]. The use of state resources in the campaigns in 2017 general elections is well documented both at the national government level and the counties level [66]. So has the harnessing of state apparatus to intimidate and frustrate the opposition in all ways possible, most of them illegal [67].

Tactic \# 7: The final major tactic is to silence their critics at any and possibly at all costs. During their trials at The Hague, UhuRuto viewed the civil society as having played a major role in assembling the evidence to indict them. From then henceforth, the civil society has been perceived by the state as an enemy and indeed has been dubbed the "evil society" by the UhuRuto support base [68]. The patriotism of civil society has often been brought to question and there have been repeated attempts to portray them as agents in the pay of foreign (and hostile) paymasters. In the post-ICC era there have been spirited attempts through legislation and outright illegal means to cripple civil society, especially those groups seen as working together with the political opposition [69]. Vugt's [70] sixth step to becoming a dictator is to accumulate power by manipulating the hearts and minds of your citizens. You do this by controlling the flow of information because such control plugs a potential channel of criticism. The lesson to be learned is therefore to control the media or, even better, own the media. UhuRuto between them own several media outlets [71]. In an unprecedented move, in January 2017 all independent television stations that attempted to air a mock swearing-in of the opposition candidate Raila Odinga were shut down and remained off the air for a number of days [72]. This was done in spite of the very robust constitutional provisions that guarantee freedom of the press.

The examples are endless and they are basically a loud proclamation of $\boldsymbol{m t a d o}$ ? The state is behaving badly with greater frequency, breaking the law and getting away with it time and again. It seems that the more the executive acts with impunity, the bolder it gets to continue along the same path. To the public, to other arms of the state and to all the institutions that are supposed to hold the executive in check, the executive is clearly and tauntingly asking mtado?! And herein lies the slippery slope into autocracy.

\section{How Kenya May Change from a Democracy to an Autocracy}

Democracies seem to work best when there is a stable economy and a population that is generally united [73]. As soon as the economy stops providing enough jobs for the people, or when politics become divisive the chances of a dictatorship emerging become very high. In the past few years unemployment in Kenya, especially among the youth, has created a large group of discontents and national politics are arguably at their most divisive since independence. As Cooke [74] has noted, a dictatorship forms from a background of interests and groups that aid the regime by finances, apologetics or aggressive support. So why would a group that is already so wealthy and privileged like Kenya's ruling class trouble itself by recourse to barbaric and complicated policies that autocratic rule implies? Although there is an element of greed and insanity in some cases, most authors on this subject seem to agree on one common thing [75-77], and that is deteriorating socio-economic conditions such as are being witnessed in Kenya today. The ruling class in Kenya can only look on in dismay as social conditions in society change in a way that they have no control over. As businesses pursue their prime objective of profit they create an ever-widening gap between the rich and the poor with the well-known result that Kenya is today one of the most unequal societies in the world [78].

Historically, the transition from democracy to dictatorship has appeared in various forms including military coups-d'-etat, civil wars, election tampering and "emergency" situations that require the conferring of "special" powers on the leadership [79]. Given Kenya's history, the two latter circumstances appear most likely because of the long history of contested electoral outcomes based on allegations of rigging and the often used arbitrary and unconstitutional exercise of special powers to put down the "emergencies" that result from such tampering. And this scenario echoes Obama's [80] comments about the rise of "strongman politics":

Look around. Strongman politics are ascendant. Suddenly, whereby elections and some pretence of democracy is maintained, the form of it, but those in power seek to undermine every institution or norm that gives democracy meaning.

It comes to a point where the poor suddenly begin making demands or begin engaging in acts of "anarchy" such as strikes, protests and even rebellions. The outcome may be a revolution from which a new order emerges or it may be a dictatorship. More often a dictatorship arises because of heightened executive powers that are justified as necessary to suppress civil unrest, create social stability and destroy the civil liberties that make protest and freedom of expression possible. Politicians commonly demand arbitrary power to deal with such situations and more often than not, the citizens themselves willingly cede them such powers. This is because in hard times many people are often willing to support even terrible things that they would find unthinkable in normal times [81]

When the ruling elite are faced with such crises they are obviously at a loss as to how to resolve the issue. The alternatives are either to remove themselves (if they are good mannered and therefore civil) or to transform this into a situation that they can continue to "manage" with strong 
arm tactics (because they are bad mannered and therefore uncivil). The latter objective is achieved by making an already bad situation worse through deliberate acts of bad manners, impunity and incivility. These have the net effect of creating chaos that can then provide the excuse for establishing a dictatorship.

\section{Conclusions}

There is really no reliable way to prevent bad or incompetent people from gaining power. Ultimately (and paradoxically), it is only the willingness to fight for good manners and civility in the public sphere that remain the most potent weapons in protection of democracy and the rule of law. When civility describes the transactions of politics then a society can avoid electing bad leaders and it can build a political system that effectively separates power with checks and balances. These make it more difficult for a dictatorship to emerge and take root. If allowed to continue unchecked, the syndrome of bad manners, incivility and impunity that have been witnessed in Kenya lately leads to a mockery of the cooperation that is the basis of society and may very well pave the way for the imposition of autocratic rule. That is to say that the promotion of bad manners, incivility and impunity by the state can only signify its desire to derail democracy. This is because the state has a moral and constitutional duty to set the standards for good manners, civility, and the rule of law. When bad manners, incivility and impunity go unchecked and finally reach uncontrollable levels lawlessness and disorder will be the result. At that time those in power who have largely been responsible for bringing about this situation in the first place can then come out with a "prescription" to tame the "anarchy" that they themselves have created. They can blithely invoke their duty to maintain the "peace" by imposing autocratic rule! Meanwhile, a large part of the public has been unwittingly carried along with the false belief that the incidences of bad manners, incivility and the impunity by the state were only necessary to maintain a mythical "peace" for their benefit [82]. By the time the people find themselves in a dictatorship, ostensibly introduced to "save" them from the epidemic of bad manners, incivility and impunity that the state itself has nurtured, it is too late and many can then only sigh with relief at this "salvation" offered by the new strongman!

\section{REFERENCES}

[1] Ndemo, B. The evolution and economics of Sheng. Online available from

https://www.nation.co.ke/oped/blogs/dot9/ndemo/2274486 -2593948-1477erlz/index.html

[2] Franceschi, L. Impunity is under siege in Kenya, and accountability will ultimately win. Online available from https://www.nation.co.ke/oped/blogs/dot9/franceschi/2274 464-4070590-packou/index.html

[3] Dzenisevich, U. Tackling police violence and impunity in Kenya: Give the Constitution a chance. Online available from

https://www.pambazuka.org/advocacy-campaigns/tackling -police-violence-and-impunity-kenya-give-constitution-cha nce

[4] Carotenuto, M. Kenya after the elections: will amnesia and impunity continue? Online available from https://africasacountry.com/2017/08/kenya-after-the-electi ons-will-amnesia-and-impunity-continue/

[5] Friedman, G. Manners and political life. Online available from https://geopoliticalfutures.com/manners-political-life/

[6] Mendieta, E. Civility at the core of American democracy, whatever politicians say. Online available from $\mathrm{http} / /$ theconversation.com/civility-at-the-core-of-american -democracy-whatever-politicians-say-67675

[7] Elias, N. The civilizing process: Sociogenetic and psychogenetic investigation, $2^{\text {nd }}$ Edition. Wiley, London, 2000.

[8] Wilson, S. What is the difference between etiquette and manners? Online available from https://www.wisegeek.co $\mathrm{m} /$ what-is-the-difference-between-etiquette-and-manners.h tm

[9] Schneck, S. No civility, no democracy. Online available from http://ipr.cua.edu/blogs/post.cfm/no-civility-no-democracy

[10] Schneck, S. No civility, no democracy. Online available from http://ipr.cua.edu/blogs/post.cfm/no-civility-no-democracy

[11] Schneck, S. No civility, no democracy. Online available from

http://ipr.cua.edu/blogs/post.cfm/no-civility-no-democracy

[12] Schneck, S. No civility, no democracy. Online available from

http://ipr.cua.edu/blogs/post.cfm/no-civility-no-democracy

[13] Hacala, S. 5 ways to bring back civility. Online available from

https://www.aarp.org/politics-society/advocacy/info-03-20 12/etiquette-manners-civility.html

[14] Wilson, S. What is the difference between etiquette and manners? Online available from https://www.wisegeek.co $\mathrm{m}$ /what-is-the-difference-between-etiquette-and-manners.h tm

[15] Mendieta, E. Civility at the core of American democracy, whatever politicians say. Online available from $\mathrm{http} / /$ theconversation.com/civility-at-the-core-of-american -democracy-whatever-politicians-say-67675

[16] Mendieta, E. Civility at the core of American democracy, whatever politicians say. Online available from http://theco nversation.com/civility-at-the-core-of-american-democrac $\mathrm{y}$-whatever-politicians-say-67675

[17] Gayet-Viaud, C. Civility and democracy. Online available from https://philpapers.org/rec/GAYCAD 
[18] Gayet-Viaud, C. Civility and democracy. Online available from https://philpapers.org/rec/GAYCAD

[19] Gayet-Viaud, C. Civility and democracy. Online available from https://philpapers.org/rec/GAYCAD

[20] Gayet-Viaud, C. Civility and democracy. Online available from https://philpapers.org/rec/GAYCAD

[21] Gayet-Viaud, C. Civility and democracy. Online available from https://philpapers.org/rec/GAYCAD

[22] Friedman, G. Manners and political life. Online available from https://geopoliticalfutures.com/manners-political-life/

[23] Haag, M. Obama speech in South Africa warns against rise of "strongman politics". Online available from https://www.nytimes.com/2018/07/17/world/africa/obamaspeech-south-africa.html

[24] Friedman, G. Manners and political life. Online available from https://geopoliticalfutures.com/manners-political-life/

[25] Nagle, A. A tragedy of Manners. Online available from https://thebaffler.com/salvos/a-tragedy-of-manners-nagle

[26] Landler, M. Bad Luck and Worse Manners Tarnish Obama's Asia Trip. Online available from https://www.nytimes.com/2016/09/07/world/asia/rodrigo-d uterte-south-china-sea-obama-snub-east-asia-summit.html

[27] Nekesa, J. Uhuru Receives Curse Warning for "Fighting" Elder Maina Wanjigi. Online available from https://www.update.co.ke/?p=10159

[28] Camp, J., Chien, Y.T. The Internet as Public Space. Online available from https://sites.hks.harvard.edu/m-rcbg/research/j.camp_acm. computer_internet.as.public.space.pdf

[29] B. Onyango-Ogutu, A. Roscoe. Keep my words. Heinemann, Nairobi, 1974.

[30] B. Onyango-Ogutu, A. Roscoe. Keep my words. Heinemann, Nairobi, 1974.

[31] E. Evans-Pritchard. The Nuer. Oxford University Press, London, 1987.

[32] Adamson, G. Is a balance between democracy and authoritarian governance the new way to go since either extremes has its flaws? Online available from https://www.quora.com/Is-a-balance-between-democracy-a nd-authoritarian-governance-the-new-way-to-go-since-eith er-extremes-have-its-flaws

[33] Acton, J.D. Quotes. Online available from https://www.google.co.ke/search?ei=UErLWqm9Eoa3Ua $\mathrm{OKk} 4 \mathrm{gP} \& \mathrm{q}=$ lord + acton $\% 27 \mathrm{~s}+$ famous + quote $\&$ oq $=$ lord $+\mathrm{ac}$ ton $\% 27 \mathrm{~s}+\&$ gs_l=psy-ab.1.2.013j0i22i30k117.5790.8779.0. 15076.13.12.0.0.0.0.539.1928.2-1j2j1j1.5.0...0...1c.1.64.ps y-ab..8.5.1925...0i67k1j0i131k1.0.ovjdo50wkos

[34] J. Tully. The Challenge of Reimagining Citizenship and Belonging in Multicultural and Multinational Societies. In C. McKinnon, I Hampsher-Monk (eds). Demands of Citizenship. Continuum, London, 2000.

[35] Spath, T., Dahnke, C. What is Civility? Online available from

https://www.instituteforcivility.org/who-we-are/what-is-ci vility/

[36] Gunderson, A.G, Lea, S.G. Let's talk politics: Restoring Civility through Exploratory Discussion. Online available from

http://www.hcs.harvard.edu/summercamp/Reading/Interact ivity\%20Foundation/Gundersen Goodney\%20Lea\%20M ANUSCRIPT\%20Ch\%206-7-8_2012_0606.pdf

[37] Arnett, R.C., Arneson, P. Dialogic civility in a cynical age. SUNY Press, Albany, 1999.

[38] Mayne, D. 12 of the most Common Bad Manners. Online available from

https://www.thespruce.com/the-most-common-bad-manner s-1216659

[39] Burnes, B., Pope, R. Negative behaviour in the workplace. Online available from

https://pdfs.semanticscholar.org/9001/300f400ea89e22b3c 72c65ad2e53f151aefd.pdf

[40] Lwanga, C., Mutavi, L. Police raid Jimi Wanjigi home in Nairobi. Online available from https://www.nation.co.ke/news/Police-raid-Jimi-Wanjigi-h ome/1056-4142306-72yj68/index.html

[41] Omollo, K. Baby Pendo died with IEBC ink on her finger and was a miracle baby coming after three miscarriages. Online available from

https://www.sde.co.ke/thenairobian/article/2001251766/tra gic-baby-pendo-died-with-iebc-ink-on-her-finger-and-wasa-miracle-baby-coming-after-three-miscarriages

[42] Kiberenge, K. Miguna in distress call as police raid his Runda home. Online available from

https://nairobinews.nation.co.ke/news/police-raid-migunas -runda-home/

[43] Haag, M. Obama speech in South Africa warns against rise of "strongman politics". Online available from https://www.nytimes.com/2018/07/17/world/africa/obamaspeech-south-africa.html

[44] Makabenta, Y. Impunity, like crime, is a national emergency. Online available from http://www.manilatimes.net/impunity-like-crime-is-a-natio nal-emergency/269736/

[45] United Nations, Economic and Social Council. Promotion and Protection of Human Rights. Online available from http://hrlibrary.umn.edu/instree/HR-protection2005.html

[46] Kalinaki, D. Kenya, the land of impunity, refuses to accept and move on. Online available from http://www.africareview.com/blogs/979192-4085910-sskb x6z/index.html

[47] Kenya National Commission on Human Rights. Counting the cost of human rights violations. Online available from http://www.knchr.org/Portals/0/CivilAndPoliticalReports/ FOOTPRINTS\%20OF\%20IMPUNITY-B5-F-T-24-7-2017 .pdf?ver $=2017-07-27-105838-067$

[48] Kalinaki, D. Kenya, the land of impunity, refuses to accept and move on. Online available from http://www.africareview.com/blogs/979192-4085910-sskb $\mathrm{x} 6 \mathrm{z} / \mathrm{index} \cdot \mathrm{html}$

[49] Kenyans for Peace Truth and Justice. Kenya's 7-Step Formula for Impunity. Online available from 
http://www.khrc.or.ke/mobile-publications/other-practicalinformation/97-kenya-s-7-step-formula-for-impunity/file.h tml

[50] . Brainy Quote. Karl Marx Quotes. Online available from https://www.brainyquote.com/quotes/karl_marx_382655

[51] Kenyans for Peace Truth and Justice. Kenya's 7-Step Formula for Impunity. Online available from http://www.khrc.or.ke/mobile-publications/other-practicalinformation/97-kenya-s-7-step-formula-for-impunity/file.h tml

[52] Wafula, P. Wanted: Will Auditor General Edward Ouko survive latest hit? Online available from https://www.stand ardmedia.co.ke/business/article/2001234808/wanted-will-a uditor-general-edward-ouko-survive-latest-hit

[53] Benjamin, I. State withdraws NASA leaders bodyguards. Online available from

https://www.the-star.co.ke/news/2018/01/31/state-withdra ws-nasa-leaders-bodyguards_c1706999

[54] International Centre for Transitional Justice. The Kenya Commission of Inquiry into Post-Election Violence. Online available from http://ictj.org/sites/default/files/ICTJ-Kenya -Dialogue-Inquiry-2008-English.pdf

[55] Human Rights Watch. "Turning Pebbles". Evading Accountability for Post-Election Violence in Kenya. Online available from

https://www.hrw.org/report/2011/12/09/turning-pebbles/ev ading-accountability-post-election-violence-kenya

[56] Evans-Pritchard, B., Jennings, S. Action Urged on ICC Witness Protection. Online available from https://iwpr.net/global-voices/action-urged-icc-witness-pro tection

[57] Human Rights Watch. Kenya: Post-Election Killings, Abuse. Online available from https://www.hrw.org/news/2017/08/27/kenya-post-election -killings-abuse

[58] Agutu, N. Uhuru praises police for job well done in election. Online available from

https://www.the-star.co.ke/news/2017/12/02/uhuru-praises -police-for-job-well-done-in-election_c1678720

[59] Oudia, R. Post-poll chaos shooting victims seek justice 10 years later. Online available from https://www.nation.co.ke/counties/kisumu/2007-post-pollchaos-victims-justice/1954182-4323380-f7urwwz/index.ht $\mathrm{ml}$

[60] Thuku, W. Officer "not guilty" of killing Kisumu demonstrators. Online available fromhttps://www.standard media.co.ke/business/article/2000012185/officer-not-guilty -of-killing-kisumu-demonstrators

[61] Hamadi, R. Uhuru "threatens" Maraga, calls Supreme Court Judges "wakora". Online available from https://hivisasa.com/posts/uhuru-threatens-maraga-calls-su preme-court-judges-wakora

[62] Njagih, M. "Evil clique of judges" out to humiliate us, says Matiang'i. Online available fromhttps://www.standardmed ia.co.ke/article/2001275553/evil-clique-of-judges-out-to-h umiliate-us-says-matiang-i

[63] Kenyans for Peace Truth and Justice. Kenya's 7-Step
Formula for Impunity. Online available from http://www.k hrc.or.ke/mobile-publications/other-practical-information/9 7-kenya-s-7-step-formula-for-impunity/file.html

[64] Miriri, D., Obulutsa, G. Kenya's ruling party moves to amend election law ahead of vote re-run. Online available from

https://www.reuters.com/article/us-kenya-election-law/ken yas-ruling-party-moves-to-amend-election-law-ahead-of-v ote-re-run-idUSKCN1C31K5

[65] Orange Democratic Movement. Exposed: President Uhuru and DP Ruto plan to use violence and rig the 2017 elections. Online available from https://www.kenya-today.com/opini on/exposed-president-uhuru-dp-ruto-plan-use-violence-rig2017-elections

[66] Ondieki, E. EU observers report on Kenya polls cites bribery, use of state resources. Online available from https://www.nation.co.ke/news/politics/EU-observers-repo rt-Kenya-elections/1064-4258456-h1flrwz/index.html

[67] Human Rights Watch. "Kill Those Criminals". Security Forces Violations in Kenya's August 2017 Elections. Online available from https://www.hrw.org/report/2017/10 /15/kill-those-criminals/security-forces-violations-kenyas-a ugust-2017-elections

[68] Mutua, M. If indeed civil society is evil, then I am a proud member of that "evil society". Online available from https://www.standardmedia.co.ke/article/2000100143/if-in deed-civil-society-is-evil-then-i-am-a-proud-member-of-th at-evil-society

[69] Jerving, S. Kenya clamps down on NGOs after elections. Online available from https://www.devex.com/news/kenya -clamps-down-on-ngos-after-election-90883

[70] Vugt, M.V. 7 steps to becoming a dictator. Online available from

https://www.jamiiforums.com/threads/7-steps-to-becoming -a-dictator-by-mark-van-vugt-ph-d.1310808/

[71] Media Watch. Ruto seeks to buy out Uhuru's media house. Online available from https://businesstoday.co.ke/ruto-eye s-controlling-stake-mediamax/

[72] Michira, M. Kenyans outraged by censorship on TV and Radio stations. Online available from https://www.standardmedia.co.ke/business/article/2001267 856/kenyans-outraged-by-state-move-to-shut-down-media

[73] Conroy, C. How do democracies become dictatorships? Online available fromhttps:/www.theatlantic.com/daily-di sh/archive/2008/09/how-democracies-become-dictatorship $\mathrm{s} / 211352$

[74] Cooke, J. Why democracies evolve into dictatorships. Online available from http://www.informationclearinghous e.info/article14605.htm

[75] Cooke, J. Why democracies evolve into dictatorships. Online available from http://www.informationclearinghous e.info/article14605.htm

[76] Powell, J. How dictators come to power in a democracy. Online available from https://www.forbes.com/sites/jimpo well/2013/02/05/how-dictators-come-to-power-in-a-democ racy/

[77] Conroy, C. How do democracies become dictatorships? 
Online available fromhttps://www.theatlantic.com/daily-di sh/archive/2008/09/how-democracies-become-dictatorship $\mathrm{s} / 211352 /$

[78] Juma, V. Kenya ranked among most unequal societies. Online available from

https://www.businessdailyafrica.com/corporate/Kenya-ran ked-among-most-unequal-societies/539550-1047230-i34iil $\mathrm{z} /$ index.html

[79] Cooke, J. Why democracies evolve into dictatorships. Online available from http://www.informationclearinghous e.info/article14605.htm

ii Pronounciation of Kiswahili word uta: $\mathbf{u}-o o$ as in goose, $\mathbf{t a}-$ as in $t a \mathrm{~d}$
[80] Haag, M. Obama speech in South Africa warns against rise of "strongman politics". Online available from https://www.nytimes.com/2018/07/17/world/africa/obamaspeech-south-africa.html

[81] Powell, J. How dictators come to power in a democracy. Online available from

https://www.forbes.com/sites/jimpowell/2013/02/05/how-d ictators-come-to-power-in-a-democracy/

[82] Carotenuto, M. Kenya after the elections: will amnesia and impunity continue? Online available from https://africasacountry.com/2017/08/kenya-after-the-electi ons-will-amnesia-and-impunity-continue/ 